\title{
The Potential of E-Learning in Assisting Post-Crisis Countries in Re-Building Their Higher Education Systems: The Case of Libya
}

\author{
Amal Rhema and Iwona Miliszewska \\ Victoria University, Melbourne, Victoria, Australia
}

Amal.Rhema@live.vu.edu.au; Iwona.Miliszewska@vu.edu.au

\begin{abstract}
In consideration of the recent crises in Libya - the political crisis, the armed conflict, and the destruction that followed - its higher education system needs to be re-built and re-developed. The use of Information and communication technology (ICT) and e-learning could play a vital role in this process. Information and communications technologies are key elements of the universal response to crises, whether natural or man-made disasters. ICTs are fundamental enablers of the coordination mechanisms that educational organizations need to restore in order to assist the affected learners and instructors. Libya is a developing country and the use of ICTs and the implementation of e-learning were still in a quite early stage even before the current armed conflict. The recent crisis resulted in a setback to Libya's e-learning efforts; however, the deployment of ICT and e-learning, assisted by the international community can provide Libya with the opportunity to significantly re-construct its education system, modernize instructional methods and, widen and improve access to higher education. This paper outlines the impact of the armed conflict on higher education in Libya. The paper discusses how ICT and e-learning could be used (as reconstructive and attractive measures) to support the affected learners and instructors in Libya. It also outlines the potential for e-learning to increase access to, and improve the relevance and quality of, higher education. In conclusion, the paper proposes an integrated approach to advancing the presence of e-learning in Libya's higher education system.
\end{abstract}

Keywords: e-learning, developing country, information and communication technology, Libyan higher education, flexible learning, post-crisis country.

\section{Introduction}

Libya has the highest literacy rate in the Arab world (Hamdy, 2007). The United Nation's Human Development Index (Hamdy, 2007), which ranks standard of living, social security, health care and other factors for development, keeps Libya at the top of all African countries; Libya has always been enthusiastic to ensure access to appropriate education for all members of the society.

Material published as part of this publication, either on-line or in print, is copyrighted by the Informing Science Institute. Permission to make digital or paper copy of part or all of these works for personal or classroom use is granted without fee provided that the copies are not made or distributed for profit or commercial advantage AND that copies 1) bear this notice in full and 2) give the full citation on the first page. It is permissible to abstract these works so long as credit is given. To copy in all other cases or to republish or to post on a server or to redistribute to lists requires specific permission and payment of a fee. Contact Publisher@InformingScience.org to request redistribution permission.
Libya's pre-2011 reforms included improvements and development of ICT infrastructure, as the country sought to develop and modernize its educational system. The adoption of ICT at all levels of education, including higher education, was an essential factor in Libya's overall development plans (Hamdy, 2007, Rhema \& Miliszewska, 2010). However, the current armed conflict has held back the human development pro- 
gress, the educational reform process, and the ICT progress in Libya.

For Libya, like most developing countries, education holds the key to the future. Libya is a large country in north central Africa with a population of just over six million people. It is a rich country, which can depend on its natural resources for economic development. Education is an essential human right and a fundamental tool to ensure that all Libyans - women and men, as well as children - realize their full potential (The General People's Committee of Education, 2008).

The political and humanitarian crisis in Libya represents an educational disaster. Education systems are destabilized, disrupted, or even destroyed. The use of ICTs and the implementation of elearning were still in a quite early stage, even before the current armed conflict. The recent crisis resulted in a further setback to Libya's e-learning efforts.

Having weathered one of the worst humanitarian crises, and with a reconstructed oil industry, Libya seems to have the potential for an economic renaissance. There are various reasons to be optimistic about Libya's prospects for re-constructing and developing a strong education system, as the youths of "seventeenth of February" revolution and the Libyan Transitional National Council have demonstrated their commitment to improve and enhance all aspects of life in Libya, including the education sector.

"The Transitional National Council (TNC) that is now responsible for running Libya has promised to not only re-open universities and colleges promptly this autumn, but also to make sweeping improvements to the education system as a whole. It remains to be seen over the coming months whether the new governing council can fulfill these promises" (Elalem, 2011). Thus, Libya can be regarded as one of the countries that are most likely to see a rapid advancement in a couple of decades. Much of this advancement will depend on the revival of Libya's education system.

In order to succeed, Libya will need international assistance and the assistance of the international community must be comprehensive and coordinated. In the educational arena, the deployment of ICT and e-learning, assisted by the international community, can provide Libya with the opportunity to significantly re-construct its education system, modernize instructional methods and facilitate access to higher education.

To understand the potential of e-learning to post-conflict Libya, this paper outlines the impact of the 2011 armed conflict on higher education in Libya. It discusses how ICT and e-learning could be used (as reconstructive and attractive measures) to support the affected learners and instructors in Libya. It also outlines the potential of e-learning to increase access to higher education and improve its relevance and quality.

\section{The Impact of the Armed Conflict on Libyan Higher Education}

Armed conflicts create a great risk and danger to lives and well-being of a large number of people around the world. Internal armed conflicts are far more frequent than inter-state conflicts (Urdal, 2004). While there was an increase in the number of internal conflicts immediately after the end of the Cold War, such conflicts now occur almost as frequently as in the late Cold War period (Urdal, 2004). The most prominent effects of these conflicts are: loss, injury, insecurity, displacement, dislocation of family and community life, and psychological trauma. These effects are also depriving students of opportunities for education that could transform their lives and spearhead sustainable development of Libya. Historical evidence confirms that incidents of armed conflict can impair or reverse education gains made over many years. Even relatively short incidents of violence can result in large setbacks and regression, as was the case in Rwanda (UNESCO, 2011a). 
The 2011 armed conflict in Libya completely transformed every aspect of the daily life, including education. It halted the progress and set back the gains built up over generations, disrupted economic growth and advances in nutrition, health, housing, education and employment. The Libyan League for Human Rights has reported that the amount of material losses reached \$575 billion (Aljazeera.net, 2011). Over the last months, the escalation of the conflict has had serious impact on the provision and service delivery of education, as the educational infrastructure has been severely damaged and schools, universities, and institutes became a place of recruitment for soldiers.

Consequently, "Many universities across the country have been closed or operating shoestring services, since Libya's rebellion started in February. [....] [It] is likely to have a lasting impact on university education in Libya. Media reports show that fighting has heavily damaged universities in Misrata” (Detrie, 2011). The considerable impact of this conflict on many Libyan cities resulted in: (1) damage and/or destruction of buildings (schools, universities, and training centers, libraries and laboratories); (2) power outages; (3) destruction of educational infrastructure and equipments such computer networks, internet servers, TV transmitters, computers, TV sets, and AV projectors; (4) unavailability of transportation, as a result of lack of fuel and security; and (5), closure of educational institutions due to detention of students and instructors, as well as kidnapping of students for obligatory recruitment into Gaddafi's fighting cadre.

In addition, many students and teachers have displaced their homes in search of safety; those students can no longer study at their educational institutions, and their teachers no longer teach there. This problem is particularly severe in the Western part of Libya in Jabal Nafusa (Aljabal Algharbi) where more than 500,000 people have left their homes and sought shelter in the state of Tunisia (Aljazeera.net, 2011). Most of the international aid for these refugees is used for food, water, shelter, and health purposes while little support is given for education. In addition, higher education students in many cities such as Ejdabia, Zawia, Zentan, Nalowt, Yefren and Misrata who found themselves in direct contact with the repressive forces of the Gaddafi's regime became 'armed people in the name of resistance and protection' dropping their studies to join the fighting (Detrie, 2011).

Generally, resistance to Gaddafi forces in the context of education has pushed many Libyan higher education students and instructors to participate in uprisings, marking the beginning of a process of large-scale 'militarization of students'. In contrast, the crisis comes amid reports that Gaddafi soldiers are moving around some campuses forcing students and instructors to join Gaddafi's fighting cadre. The conflict has also exposed students and instructors to a variety of dangers including psychological danger (feeling of fear, distress and trauma), physical danger (increasing level of violence in schools and universities, and sexual abuse), and harmful effects on the educational environment for safe and creative learning for students.

Another effect is the shortage of instructors in the affected areas caused by death or displacement; this is likely to necessitate multi-institute and multi-grade teaching solutions and significantly increased workload for the remaining instructors in most of the universities and institutes. Furthermore, most teachers lost the opportunity to participate in training programs due to a lack of security. Consequently, due to implications on availability and access, the motivation of students and instructors for education and training has been severely reduced and, the educational institutions in most parts of Libya have been rendered unable to function.

\section{E-learning as Promising Option in Supporting Libyan Higher Education}

To re-start the Libyan education system, the Libyan higher education students and instructors require a very flexible environment (a technology-mediated learning environment) that would im- 
prove access to higher education, help modernize instructional methods, and support and assist learning. This is where ICT comes in. The advancements of new technologies and the Internet have had a significant impact on teaching and learning in higher education (Hodges, 2004; Smith \& Winking-Diaz, 2004).

This made developing countries realize the importance and potential of ICT and e-learning in gaining prosperity and developing education and human resources (Bhatti, Tubaisahat, \& ElQawasmeh, 2005). Libya is a developing country and, even before the current armed conflict, the use of ICTs and the implementation of e-learning were still in a quite early stage (Hamdy, 2007; Rhema \& Miliszewska, 2010); the Libyan education system was still a traditional system, based on face-to-face interactions and campus-based learning activities (Rhema, \& Miliszewska, 2010). This traditional classroom setting has been severely affected by the current armed conflict. Thus, other means of teaching and learning have to be sought and introduced.

E-learning appears to be a promising alternative (Rhema, \& Miliszewska, 2011). It can provide learning opportunities anytime anywhere. It enables students and instructors to use a wide range of Internet based tools to communicate, collaborate and share resources, and open up accessible educational opportunities. ICT and e-learning could be used (as reconstructive and attractive measures) to support the affected learners and instructors in Libya, as well as to make the learning environment a place to pass information and knowledge from teacher to students, from students to teacher, and from students to students, and a place for creative thinking, and learning. Even before the current armed conflict, e-learning seems to have provided responses to several educational problems in Libya, as illustrated by Rhema (2005) and Rhema and Miliszewska (2010). It afforded alternative ways of communicating with teachers and fellow students, provided a greater variety of learning resources and modalities, extended the flexibility and quality of group-work, and improved the opportunities for providing students with feedback on assessment tasks (Rhema, \& Miliszewska, 2011).

\section{The Potential of Technology-Assisted Learning to Increase Access to Higher Education and Improve Its Relevance and Quality}

"Creative and innovative applications of information and communication technologies (ICTs) have long been seen as important potential tools to enable educational reform processes improving both access to education, and the quality of that education” (The World Bank, 2010). ICT can increase access to education through distance learning, enable a knowledge network for students, train teachers, and broaden the availability of quality education materials.

Generally, ICTs can be essential operators for educational reform, utilized as a control for organizational change, as a way to introduce new teaching and learning practices and/or as an enabler and key factor of re-structuring of the educational system. ICTs can be used to extend access to educational delivery models, to support the ongoing professional development of teachers, and to facilitate education-related data collection and processing efforts in ways previously not possible (The World Bank, 2010). Therefore, emerging ICT tools offer new opportunities to affected Libyan higher education students and instructors.

However, it is important to remember that post-war Libya will lack high speed internet access and adequately trained personnel. The training of academic staff in the use of ICTs to deliver online training will be vital. In this context, Libyan universities have no choice but to significantly alter their instructional methods by using ICT to keep pace with the developments spurred by technology advancements. During this stage, there is a great need for appropriate ICTs to help address the educational gaps, and open up accessible educational opportunities for Libyan higher educa- 
tion educators. Appropriate ICTs are those which are "suitable for the cultural, environmental, organizational, economic and political conditions in which it is intended to be used" (Van Reijswoud, 2009).

Earlier ICTs such as films, videotapes, telephones, television and radio can play a critical role in reinvigorating Libyan education. Radio and TV have been providing educational programming in some countries for many years. They have been utilized successfully as a mechanism for reaching out-of-school youth in a number of countries, especially in Mexico and China. The brilliant success of the Telesecundaria Project (closed-circuit television pilot project) in Mexico encouraged the government to open an additional 4,500 Telesecundaria schools enrolling 250,000 more students between 1998 and 2002. According to a World Bank Report, the China TV University system enrols over half a million students in degree programs and graduates over 100,000 per year (UNESCO, 1999). A TV channel "Iraqi Edu" has been used to increase access to education for affected Iraqi students enrolled in the formal schooling system and out-of-school, IDP and refugee students (UNESCO, 2011c).The "Distance Learning / Educational TV" project has also assisted Iraqi people in addressing and anticipating the difficulties regarding the development and reform of the Iraqi educational system such as shortage of trained and qualified administrators, planners and teachers, teaching/learning materials, quality teaching facilities and aids, and the deteriorating economic conditions leading to youth seeking gainful employment during school hours (UNESCO, 2011c). The Open Learning Systems Education Trust (OLSET), based in South Africa, developed audio- and print-based distance education programs for direct use in classrooms (Farrell \& Shafika, 2007). Although Radio and TV are not new technologies, they have been successfully applied to assist and facilitate the educational process in many developing countries.

Second-hand and refurbished PCs, which are procured from groups like Computer Aid International, Digital Links, SchoolNet Africa, and World Computer Exchange, have been used in many African countries. Schoolnet organizations in Cameroon, Mali, Mozambique, Namibia, Nigeria, Kenya, Uganda, Zambia, and Zimbabwe have sourced second-hand and refurbished PCs. Mobile phones have also been used for learning in South Africa with the piloting of the Math on MXit and MobilEd programs by the Meraka Institute, as well as short message system (SMS) between teachers and students has also been used in Kenya (Farrell \& Shafika, 2007).

In Egypt, the Faculty of Engineering at the University of Cairo is setting an example with ICT related activities such as conversion of text books to interactive CD-ROMs and pilot projects in virtual classrooms. Also, the American University in Cairo is using WebCT as a learning management system and offering a centre to help the university teachers convert their materials to web-friendly format (Abdel-wahab, 2008 cited in Rhema \& Miliszewska, 2010).While in Tunisia, Waheeb is widely used as a Web-based learning platform that provides a fully integrated student environment, learning management system, and a range of custom content creation and publication tools (Chorfi \& Jemini, 2002 cited in Rhema, \& Miliszewska, 2010).

In addition, e-books have successfully been used as a medium of teaching and learning in many countries. Mohammed Aly and Gabal (2010) presented a critical review of research pertinent to the use of e-books at Physical Education Faculty, Menoufiya University in Egypt. They found that e-books have more effective and positive influence on teaching formations and configurations, body positions, and physical exercises in physical education lessons as well as on learning, when compared with the printed books.

These successful initiatives and experiences in many developing countries can serve as powerful examples for Libyan institutions that may follow their strategies to fulfil the potential of ICT for teaching and learning and to achieve rapid technological development. They can provide a posttrauma solution for Libyan educators to assist them in restarting the educational process, expand- 
ing access to education, and improving the quality of education at Libyan higher education institutions.

\section{Restarting the Educational Process}

ICTs and e-learning are fundamental enablers of the coordination mechanisms that educational organizations need to restore to assist the affected Libyan learners and instructors. They are useful methods in generating and managing a variety of teaching and learning resources, and support services and products, such as course outlines, digitally recorded classroom material, discussion groups, laboratory manuals and lab assignments, lecture notes, live lectures for later viewing and re-viewing, links to course specific websites, online tutorials, supplementary readings, and virtual office hours for teacher-student consultations.

TV has been providing successful and interesting educational programming in many developing countries. National Geographic, the Discovery Channel, the History channel, and Mindset Learn have been employed successfully as educational channels via satellite broadcast in a number of African countries (Farrell \& Shafika, 2007). TV appears to be a promising educational solution for the affected Libyan students. It can provide an interesting mechanism to assist the Libyan students and instructors in restarting the educational process and it is a readily-available technology - no investment cost.

In addition, ICT may act as a powerful instrument to attract the affected Libyan learners and instructors and to change many of the educational practices to which they have become accustomed. Virtual libraries and e-books, if provided, could be particularly useful, as they could substantially reduce the costs of acquiring expensive textbooks, journals, and reference materials (UNESCO, 2009). Mohammed Aly and Gabal (2010) stated that e-books have positive effects on learning because of the effectiveness and attractiveness of computers in general and e-reading in particular. They also reported that through the interaction between students and computer, as students chose the material and controlled the sequence of subjects and time, e-reading of printed books improved student engagement and supported them in achieving the best learning outcome without feeling boredom.

ICT may have a positive impact on student motivation (Achimugu, Oluwagbemi \& Oluwaranti, 2010; Aktaruzzaman, Shamim \& Clement, 2011; Andersson \& Grönlund, 2009; Grabe \& Grabe, 2007; Kelleher, 2000; Skinner \& Preece, 2003). For example, using new technologies such as podcasts, digital video and Wikis, increased student motivation in the science classroom (de Winter, Winterbottom \& Wilson, 2010). According to authors, such as Bottino (2004), Christophersen (2006), Crison, Lerman \& Winbourne (2007), using ICT in teaching presents a number of advantages when compared to more traditional educational recourses used in classrooms. These advantages are instructional flexibility, increased motivation, companioned by greater involvement in learning process, collaborative and cooperative activities. As pointed by Garaia \& Romeo (2009, p.392), "in general, ICT produced increased motivation, improved behaviour and an improved paced of work in the students, especially apparent in those groups that were characterized by a lack of interest in learning”.

Many researches indicate that ICT increases student engagement because it provides opportunities to shift from teacher-centred to student-centred learning which attracts students and lead them to enjoy learning (Rhema \& Miliszewska, 2010). For example, using ICT as an instructional medium will likely change many of the traditional strategies employed by both Libyan students and instructors in the learning process, which may motivate and encourage them to restart the educational process and move to different models of teaching and learning such as student-centred teaching and problem-based learning (Oliver, 2002). 
In addition, the integration of ICT has the potential to increase the enthusiasm of the affected Libyan learners and instructors towards learning and make them active participants in their own instruction. It is also likely to develop a sense of a learning community and provide students and instructors with a sense that they are part of a friendly, interactive learning environment. They could participate in chat room and forum discussions, produce and share digital visual content on mobile devices, mobile phones, flip cameras, iPhones and the iPod Touch (if available).

\section{Expanding Access to Education}

In view of the deterioration of security conditions in some areas of Libya, the shortage of teachers as well as the closure of many educational institutions, Libya needs to ensure access to education for its students. In this context ICT can play a critical role to ensure the provision of learning opportunities to affected Libyan students, who lack basic living resources and live with an underdeveloped educational infrastructure in post-war environment.

Television broadcast has been used as a medium for delivery of education content in different countries for expanding educational opportunities, as is the case with Mindset Network and the Learning Channel in South Africa, and the Talk Back TV on HIV/AIDS program in Botswana. Interactive radio instruction (IRI) has also been used extensively by organisations like the Kenya Institute of Education, which has a radio broadcast studio and which has reached up to 400 schools via satellite radio in partnership with WorldSpace (Farrell \& Shafika, 2007). IRI is used effectively to overcome obstacles of access in Africa and to increase the chances that students can receive an education. Remote areas such as agricultural areas of the Dominican Republic and worksites of adults and youths in Honduras are benefiting from IRI; as it is being introduced as a means of serving hard-to-reach populations (The World Bank, 2005). ICT-based educational delivery (e.g., educational programming broadcast over radio or television) can facilitate better access to educational opportunities to meet the needs of Libyan students from remote and isolated areas.

However, certain types of ICTs, such as teleconferencing technologies, enable instruction to be received simultaneously by multiple, geographically dispersed learners (i.e., synchronous learning). Using mobile phone as a platform for e-learning (m-learning) where content is delivered via text messaging, can be particularly useful at a time when the necessary internet infrastructure does not exist. E-books can also offer and improve access to content, increase the speed and distribution of knowledge and provide a great promise for improving affordability.

Online and distance learning can help to address the universal demand for education, particularly in higher education, by expanding access to experts, curriculum and learning materials. They can "address all four human rights to enable not only availability and accessibility, which are strengths of online learning, but also acceptability and adaptability, which are strengths of Open Educational Resources (OER)" (Geith \& Vignare, 2008, p. 123). "It is widely suggested that online technologies can help address issues of educational equity and social exclusion, and open up democratic and accessible educational opportunities” (Gulati, 2008). Online learning and OER hold promise for lower costs and scalability for both existing and new types of institutions; they also hold promise for extending learning beyond the traditional boundaries of the virtual and physical classroom (Geith \& Vignare, 2008).

The use of ICTs in Libya's education system can support the learning process by delivering instruction to students and facilitating communication anytime and anywhere. For example, online course materials, may be accessed 24 hours a day, 7 days a week, and updates can be made available instantaneously. Instructors can contact students whenever they wish and respond to student questions at their convenience; and students can communicate (synchronously and asynchronously) with each other or with their instructors anywhere and anytime. 
Additionally, ICTs can facilitate access to remote learning resources (Achimugu, Oluwagbemi \& Oluwaranti, 2010; Aktaruzzaman, Shamim \& Clement, 2011). The Libyan students and instructors would no longer have to rely only on printed books and other materials in physical media placed in libraries for their educational needs. Through the Internet, a large amount of learning materials in almost every subject and topic in a variety of media could be accessed from anywhere at any time.

\section{Improving the Quality of Education}

ICTs are increasingly deployed as instruments to widen the learner's capacity to perceive, understand, and communicate in countries destroyed by war. ICT plays a significant role in improving the education system and the quality of learning in post-war Iraq, which has suffered greatly following Iraq's wars. The "ICT in Education for Iraq" project aims to integrate ICT at all levels of education for the continuing quality improvement of teaching and learning (UNESCO, 2011b). This can provide a powerful and useful example for Libya that may adopt Iraq's ICT strategies for helping revitalize its education system and improve the quality of education and training.

Since the mid-1990s, numerous Interactive Radio Instruction (IRI) initiatives have been initiated in Africa to improve the quality of education. In most cases, students demonstrate progressively greater increases in achievement over time (Bosch, 1997). IRI evaluations have shown consistent and significant evidence that IRI can increase and improve learning gains (Murphy et al., 2002). In Guinea, IRI is used in many educational programs; the evaluation results of these initiatives indicate that improvements in educational quality are coupled with increased enrollment, attendance, and achievement for both boys and girls in urban and rural settings (The World Bank, 2005). Whereas, in South Africa, students who received less than 33 'English in Action' lessons improved by $6.7 \%$, students who received between 34 and 66 lessons improved by 13\%, and students who received more than 66 programs improved by 24\% (Leigh, 1995; Bosch, 1997). Moreover, interactive radio makes students willing to listen and become involved in the lessons being delivered (Achimugu, Oluwagbemi \& Oluwaranti, 2010; Aktaruzzaman, Shamim \& Clement, 2011).

Challenging and reliable content that will engage the affected Libyan student in the learning process can be provided by ICTs tools such as videos, television, and multimedia computer software that include text, sound, animations and colourful, moving images; this will improve the benefits of the education on the students as it will enhance student skills and achievement (Grabe \& Grabe, 2007; Murphy, 2006; Newton \& Rogers, 2003; Yang, 2009).

Goldberg, Russell and Cook, (2003) presented a critical review of research pertinent to the effect of computers on students writing; the study employed meta-analytic techniques to integrate the findings of studies conducted from 1992 until 2002. The review indicates that instructional uses of computers for writing have a positive impact on student writing, both in terms of quantity and quality. Thus computers are a valuable tool for assisting Libyan students in developing their writing skills.

E-books also have positive and effective effect on skillful learning and give opportunity for quality learning (Mohammed Aly \& Gabal, 2010). It is obvious that networked computers with Internet connectivity can increase learner motivation as it merges the rich media resources and interactivity of other ICTs with the opportunity to connect with instructors and other fellow students. This fact can be observed by the popularity of online learning programs and the use of the computer as a learning support tool in the classroom (Paas, 2008).

Newton and Rogers (2003) stated that ICT can facilitate clearer thinking and develop interpretation skills with data. In addition, ICTs can also be used to raise the efficiency of Libyan instructors, as they can be used to improve access to and the quality of educators training (Achimugu, 
Oluwagbemi \& Oluwaranti, 2010; Aktaruzzaman, Shamim \& Clement, 2011). Therefore, ICTs can be considered as vital methods for provision of appropriate training to Libyan instructors at different levels.

\section{Conclusion}

This paper reflected on the impact of the armed conflict on higher education in Libya. It discussed how ICT and e-learning could be used to support the affected learners and instructors in Libya and outlined the potential for ICT and e-learning to increase access to, and improve the relevance and quality of, higher education.

Libya is facing major challenges following the 2011 armed conflict, which left the country in a dismal state and forced it to "start from scratch" in building up its infrastructure and services. One of the challenges is the reconstruction and redevelopment of the country's education system. Most of the educational institutions in the affected areas have lost their infrastructure and resources. These losses have to be replaced with up-to-date educational infrastructure to enable a revival of the Libyan education system.

The international community can help Libya take advantage of the opportunity to re-construct its education system, modernize instructional methods and, improve access to higher education; this assistance could include provision of portable teaching and learning devices (notebooks, iPads, mobile devices), teaching and learning content (electronic teaching and learning resources including course materials, training packages, e-books), and training courses for instructors.

Further research is needed to explore and determine the characteristics, enablers, and challenges of educational settings as related to ICT and e-learning in higher education in post-conflict Libya. One such research study, conducted by one of the authors of this paper, is currently underway. The study will investigate the experiences with, and perceptions of ICT, among students and educators in selected higher education programs in Libya to determine their potential to adopt ICT and e-learning in teaching and learning. It is hoped that the findings of the research study will serve as source of information for academics, administrators, and decision-makers involved in planning, design and implementation of e-learning in Libya.

\section{References}

Abdel-wahab, A. (2008). Modeling students' intention to adopt e-learning a case from Egypt. Turkish Online Journal of Distance Education, 9(1), 157-168.

Achimugu, P., Oluwagbemi, O., \& Oluwaranti, A. (2010). An evaluation of the impact of ICT diffusion in Nigeria's higher educational institutions. Journal of Information Technology Impact, 10(1), 25-34. Retrieved July 6, 2011 from http://www.jiti.net/v10/jiti.v10n1.025-034.pdf

Aktaruzzaman, M., Shamim, M., \& Clement, C. (2011). Trends and issues to integrate ICT in teaching learning for the future world of education. International Journal of Engineering \& Technology, 11(3), 114-119. Retrieved July 6, 2011 from http://www.ijens.org/Vol\%2011\%20I\%2003/1186030202\%20IJET-IJENS.pdf

Aljazeera News Media, Libyan News. (April 2011). www.aljazeera.net, (Accessed Online).

Andersson, A., \& Grönlund, A. (2009). A conceptual framework for E-learning in developing countries: A critical review of research challenges. The Electronic Journal on Information Systems in Developing Countries, 38(2), 1-16.

Bhatti, A., Tubaisahat, A., \& El-Qawasmeh, E. (2005). Using technology-mediated learning environment to overcome social and cultural limitations in higher education. Issues in Informing Science and Information Technology, 2, 67-76. 
Bosch, A. (1997). Interactive radio instruction: Twenty-three years of improving educational quality. The World Bank, 1(1). Retrieved October 2, 2011 from http://wwwwds.worldbank.org/servlet/WDSContentServer/WDSP/IB/1997/01/01/000009265_3980429110717/Re ndered/PDF/multi_page.pdf

Bottino, R. (2004). The evolution of ICT-based learning environments: Which perspectives for the school of the future? British Journal of Educational Technology, 35(5), 553- 367. Retrieved July 6, 2011 from http://www.itd.cnr.it/telma/docs/ITD/Bottino__ revised.pdf

Christophersen, P. (2006). ICT and learning. Victorian Curriculum and Assessment Authority, 1(2006). Retrieved July 11, 2011 from http://vels.vcaa.vic.edu.au/downloads/supportmaterials/ictdomaininfo/feature_Feb06_7-12.pdf

Chorfi, H., \& Jemini, M. (2002). Innovative e-learning experimentations by use of Waheeb, A Tunisian platform. EDEN Second Research Workshop. Germany.

Crison, C., Lerman, S., \& Winbourne, P. (2007). Mathematics and ICT: A framework for conceptualising secondary school mathematics teachers' classroom practices. Technology, Pedagogy \& Education, 16(1), 21-39.

Detrie, M. (2011). LIBYA: New regime plans to reopen universities soon. University World News, 187. Retrieved October 06, 2011 from http://www.universityworldnews.com/article.php?story=20110831125409314

de Winter, J., Winterbottom, M., \& Wilson, E. (2010). Developing a user guide to integrating new technologies in science teaching and learning: Teachers' and pupils' perceptions of their affordance. Technology, Pedagogy and Education, 19(2), 261-267.

Duan, Y., He, Q., Feng, W., Li, D., \& Fu, Z. (2010). A study on e-learning take-up intention from an innovation adoption perspective: A case in China. Computers and Education, 55(1), 237-246.

Elalem, S. (2011). LIBYA: Students speak about the rebellion, the future. University World News, 188. Retrieved October 06, 2011 from http://www.universityworldnews.com/article.php?story=2011090919081343\&mode

Farrell, G., \& Shafika, I. (2007). Survey of ICT and education in Africa: A summary report, based on 53 country surveys. Washington, DC: infoDev / World Bank. Retrieved September 21, 2011 from http://www.infodev.org/en/Publication.353.html

Garaia, M., \& Romeo, I. (2009). The influence of new technologies on the evolution of learning and on attitudes towards mathematics in secondary students. Electronic Journal of Research in Educational Psychology, 7(1), 369-396. Retrieved July 11, 2011 from http://www.investigacionpsicopedagogica.org/revista/articulos/17/english/Art_17_306.pdf

Geith, C., \& Vignare, K. (2008). Access to education with online learning and open educational resources: Can they close the gap? Journal of Asynchronous Learning Networks, 12(1), 105-126.

The General People's Committee of Education. (2008). The development of education. National report of Libya, Geneva 25- 28 November 2008. Retrieved May 14, 2011 from http://www.ibe.unesco.org/National_Reports/ICE_2008/libya_NR08.pdf

Goldberg, A., Russell, M., \& Cook, A. (2003). The effect of computers on students writing: A meta analysis of studies from 1992-2002. Journal of Technology, Learning, and Assessment, 1(2), 1-52.

Grabe, M., \& Grabe, C. (2007). Integrating technology for meaningful learning (5th ed.). Boston, MA: Houghton Mifflin.

Gulati, S. (2008). Technology-enhanced learning in developing nations: A review. International Review of Research in Open and Distance Learning, 9(1).

Hamady, A. (2007). ICT in education in Libya. Libya Country Report. Retrieved May 12, 2011 from http://www.infodev.org/en/Document.412.pdf 
Hodges, C. (2004). Designing to motivate: Motivational techniques to incorporate in e-learning experience. The Journal of Interactive Online Learning, 2(3).

Kelleher, P. (2000). A review of recent developments in the in use of in the use of information and communication technology (ICT) in science classroom. Australian Science Teachers Journal, 46(1), 33-38.

Leigh, S. (1995). Changing times in South Africa: Remodeling interactive learning. Washington DC: Learntech, Learntech Case Study Series no. 8.

Mohammed Aly, A., \& Gabal, R. (2010). Effect of using e-book and programmed paper book on some learning aspects of physical education lesson (Comparative Study). World Journal of Sport Sciences, 3(4), 261-268. Retrieved September 29, 2011 from http://www.idosi.org/wjss/3(4)10/5.pdf

Murphy, C. (2006). The impact of ICT on primary science. In P. Warwick, E. Wilson \& M. Winterbottom (Eds.), Teaching and learning primary science with ICT (pp. 13-32). Berkshire, England: Open University Press.

Murphy, P., Stephen, A., Andrea, B., \& Jeanne, M. (2002). Enhancing learning opportunities in Africa: Distance education and information and communication technologies for learning. World Bank, Washington, D.C. Retrieved September 28, 2011 from http://siteresources.worldbank.org/AFRICAEXT/Resources/dl_ict_education.pdf

Newton, L., \& Rogers, L. (2003). Thinking frameworks for planning ICT in science lessons. School Science Review, 84(309), 113-120.

Oliver, R. (2002). The role of ICT in higher education for the 21st century: ICT as a change agent for education. Higher Education 21 Conference. Retrieved July 06, 2011 from http://elrond.scam.ecu.edu.au/oliver/2002/he21.pdf

Paas, L. (2008). How information and communications technologies can support education for sustainable development. International Institute for Sustainable Development. Report. Retrieved June 30, 2011 from http://www.ictliteracy.info/rf.pdf/ict_education_sd_trends.pdf

Rhema, A. (2005). Towards flexible learning: implementing web-based learning in the Data Analysis Department of the Faculty of Economics and Accounting of the "Aljabal algharbi University" in Gharian in Libya. Unpublished Master thesis, Faculty of Behavioural Science, University of Twente, Enschede, The Netherlands.

Rhema, A., \& Miliszewska, I., (2010). Towards e-learning in higher education in Libya. Issues in Informing Science and Information Technology, 7, 423-437.

Rhema, A., \& Miliszewska, I., (2011). Reflections on a trial implementation of an e-learning solution in a Libyan university, Issues in Informing Science and Information Technology, 8, 61-76.

Rossiter, D. E., \& Crock, M. (2006). Embedding e-learning: a new perspective on change and innovation, International Journal of Learning Technology, 2(4), 279-293.

Skinner, N., \& Preece, P. (2003). The use of information and communication technology to support the teaching science in primary schools. International Journal of Science Education, 25(2), 205-219.

Smith, M., \& Winking-Diaz, A. (2004). Increasing students' interactivity in an online course. The Journal of Interactive Online Learning, 2(3).

UNESCO. (1999). New directions of ICT-use in education. Report. Retrieved September 21, 2011 from http://www.unesco.org/education/educprog/lwf/dl/edict.pdf

UNESCO. (2009). ICTs for higher education. Report. Retrieved July 5, 2011 from http://unesdoc.unesco.org/images/0018/001832/183207e.pdf

UNESCO. (2011a). The hidden crisis: Armed conflict and education. Report. Retrieved May 5, 2011 from http://unesdoc.unesco.org/images/0019/001907/190743e.pdf 
UNESCO. (2011b). Information and communication technologies for education. Report. Retrieved October 15, 2011 from http://www.unesco.org/new/en/iraq-office/education/primary-and-secondaryeducation/ict-in-education/

UNESCO. (2011c). Out of school, children learn at home thanks to the Iraqi Education Channel. Retrieved October 15, 2011 from http://www.unesco.org/new/en/iraq-office/education/primary-and-secondaryeducation/distance-learning/

Urdal, H. (2004). The devil in the demographics: The effect of youth bulges on domestic armed conflict, 1950-2000. The World Bank. Social Development Paper. Retrieved May 5, 2011 from http://wwwwds.worldbank.org/external/default/WDSContentServer/WDSP/IB/2004/07/28/000012009_20040728 162225/Rendered/PDF/29740.pdf

Van Reijswoud, V. (2009). Appropriate ICT as a tool to increase effectiveness in ICT4D: Theoretical considerations and illustrating cases. The Electronic Journal on Information Systems in Developing Countries, 38(9), 1-18.

The World Bank. (2005). Improving educational quality through interactive radio instruction. Report. Retrieved September 28, 2011 from http://siteresources.worldbank.org/EXTAFRREGTOPDISEDU/Resources/WBIRItoolkit_05.pdf

The World Bank. (2010). ICTs \& education: Issues and opportunities. Report. Retrieved June 30, 2011 from http://siteresources.worldbank.org/EDUCATION/Resources/ESSU/4632921290618190826/Background_Note_EducationStrategy2020_ICT_Edu.pdf

Yang, Y. (2009). Examining university students' and academics' understandings of ICTs in higher education. International Education Research Conference, 30 November - 4 December 2008, Brisbane, 1-13. Retrieved July 6, 2011 from http://www.aare.edu.au/08pap/yan08183.pdf

\section{Biographies}

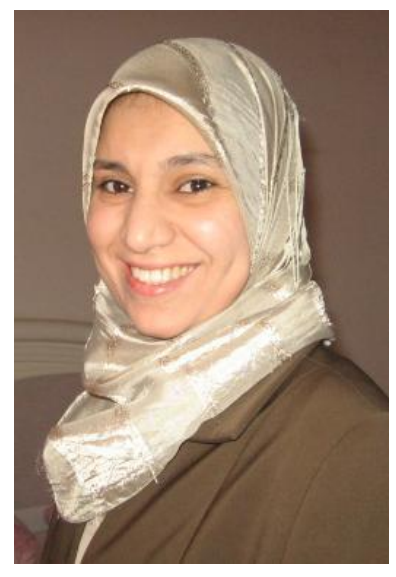

Mrs Amal Rhema is a $\mathrm{PhD}$ candidate in the School of Engineering and Science at Victoria University in Melbourne, Australia where she is currently undertaking a research project entitled "An analysis of experiences and perceptions of technology-based learning in higher education institutions in Libya: informing the advancement of e-learning through case studies".

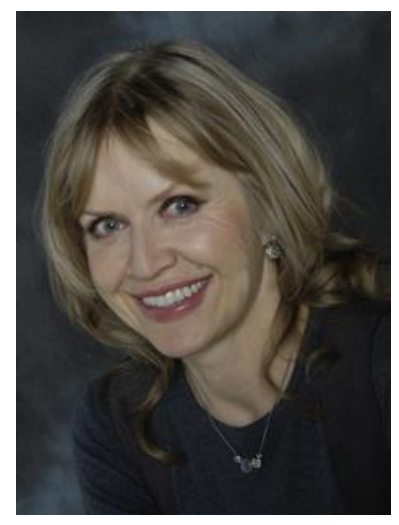

Dr Iwona Miliszewska is Associate Professor in computer science at Victoria University in Melbourne, Australia. She has led and participated in research projects involving transnational education, effective teaching methods, females in ICT, and technology supported learning and has published in these areas. 